\title{
Multivariate analyses of the role of environmental factors in seasonal and site-related growth variation in the Pacific oyster Crassostrea gigas
}

\author{
James R. Brown \\ Department of Biological Sciences, Simon Fraser University, Burnaby, British Columbia, Canada V5A 1S6
}

\begin{abstract}
Monthly increases in shell height were measured for 2 age classes (Years 0 and 1) of a common broodstock of oysters Crassostrea gigas in 10 locations in British Columbia, Canada, over 14 mo. Measurements were also taken of several environmental variables known to affect oyster growth. Based on comparisons of shell height growth curves, sites were grouped into low, medium and high growth categories which were similar for both age classes of oysters. According to discriminant function analysis, differences in salinity and particulate organic matter (POM) concentration distinguished low growth sites from medium and high growth areas. Medium and high growth areas were segregated solely on the basis of food-related variables: POM, carotenoid concentration and Secchi depth. In multiple regression analysis, chlorophyll b concentration and water temperature were significantly correlated (for both age classes; $r^{2}=0.34, p<0.001$ ) to $\log _{10}$-transformed monthly instantaneous growth rate $\left(G_{30}\right)$ with chlorophyll $b$ being the more important variable. Inclusion of monthly initial shell height in the regression analysis increased $I^{2}$ to 0.62 and 0.44 for Year 0 and Year 1 equations $(p<0.001)$, respectively. Correlation of chlorophyll $b$ to $G_{30}$ may be indicative of the role of small nanoplankton in oyster diets. Monthly oyster growth rates were prmarily regulated by food supply with temperature a secondary factor. Growth rates were highly site-specific depending on food supply and salinity conditions.
\end{abstract}

\section{INTRODUCTION}

The rapid growth, high meat yield and relative robustness of the Pacific oyster Crassostrea gigas Thunberg, has led to its introduction into many parts of the world for aquaculture. Growth in marine bivalves is affected by the interactions of several environmental variables, particularly water temperature and food supply (reviewed in Bayne \& Newell 1983). Growth studies have generally involved laboratory or field experiments which either manipulate conditions or monitor natural variation of these variables (Malouf \& Breese 1977, Bayne \& Newell 1983, MacDonald \& Thompson 1985). Univariate laboratory studies have indicated that other variables act as limiting factors to oyster growth, including salinity (Bernard 1983), dissolved oxygen (Davis 1975),pH (Kuwantani \& Nishii 1969) and suspended sediments (Loosanoff \& Tomers 1948). Bivalve growth in nature is clearly a function of several environmental variables; however, multivariate techniques have been seldom used to interpret data.
In 5 Pacific oyster culture areas in Washington State, USA, Westley (1965) attempted to relate monthly conditions of several environmental variables to oyster condition index or ratio of dried meat weight to internal cavity volume. However, oyster-environment relationships were not analysed using rigorous statistical methods and condition index is not a suitable indicator of growth (Lucas \& Beninger 1985, Brown \& Hartwick in press b). More recent studies have developed regression models which predict growth of oysters Crassostrea virginica Gmelin and C. gigas based on water temperature and monthly weight (Dame 1972 Hall 1984). Food availability may have an equal if not greater influence upon bivalve growth rates compared with temperature as evident from inter-site comparisons within a relatively narrow latitudinal range (Bayne \& Newell 1983, MacDonald \& Thompson 1985, Brown \& Hartwick 1988, in press a)

Some studies have used multivariate analyses to describe either production or growth of natural bivalve populations. Appeldoorn (1983) applied principal com- 
ponent analysis to examine the influence of environmental factors upon growth of soft-shell clams Mya arenaria L. at 25 locations. Ulanowicz et al. (1982) derived predictive equations for landings of clams in Chesapeake Bay, USA, from water temperature and salinity data. In the same region, spatfall of Crassostrea virginica was correlated to salinity, precipitation and harvest of previous years (Ulanowicz et al. 1980).

A central issue in aquaculture is performance of exotic stocks in a new habitat rather than production of indigeous populations. Dickie et al. (1984) showed that a strain of mussels Mytilus edulis L. growing in their native 'harsh' environment had a significant growth advantage over mussels transplanted from an area with more favourable conditions. Incze et al. (1980) found that a common broodstock of mussels transplanted to 7 different locations in an estuary exhibited site-specific growth rates.

In the present study, influences of environmental factors upon site-specific and seasonal growth trends of a common broodstock of Pacific oysters, in 10 locations, were analysed using multivariate techniques. Discriminant analysis was used to determine which variables best distinguished between sites with significantly different oyster growth rates. Multiple regression analysis served to relate within-site growth variation to seasonal environmental conditions.

\section{METHODS}

Ten study sites along the coast of British Columbia, Canada, were monitored monthly between June 1984 and August 1985, except for January 1985 (Fig. 1). To achieve a wide variation of habitat conditions, sites were selected in existing oyster culture areas as well as in areas where environmental conditions or conflicting coastal developments restricted commercial culture. At each site, 2 age classes of single oysters from a common seed-stock were placed in separate 5-tier lantern nets (30 cm diameter $\times 1 \mathrm{~m}$ ). Age classes were designated as Year 0 and Year 1 and had initial mean shell heights

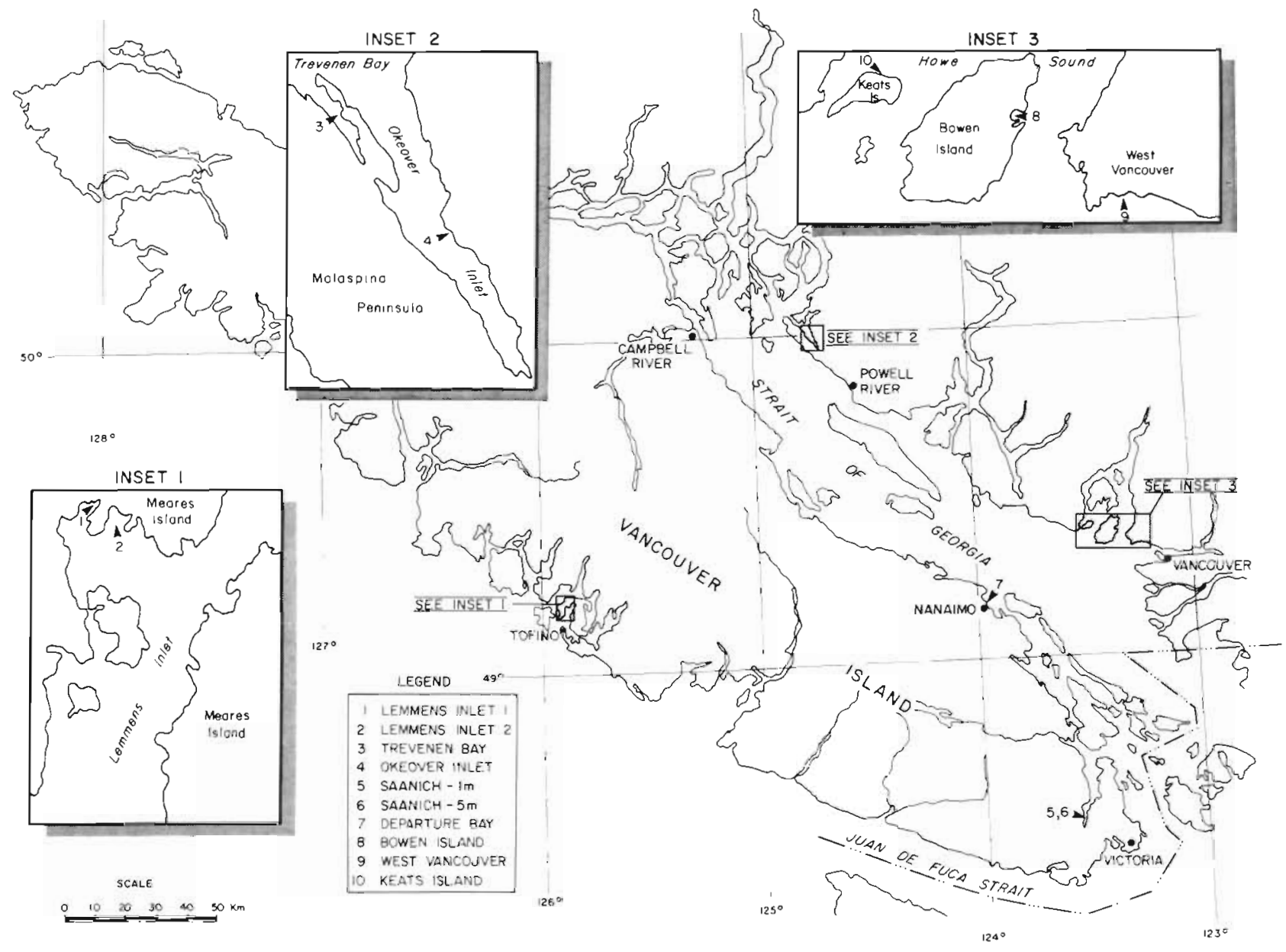

Fig. 1. Locations of study sites, British Columbia, Canada 
of $21.6 \mathrm{~mm}$ ( \pm 5.4 standard deviation [SD]: $\mathrm{n}=158$ ) and $45.2 \mathrm{~mm}$ ( $\pm 8.9 \mathrm{SD} ; \mathrm{n}=160$ ), respectively. Ca 160 to 170 oysters were spread evenly among net tiers in order to minimize density effects upon growth. All nets were attached to floating platforms and tops of nets remained at $1 \mathrm{~m}$ below surface throughout a tidal cycle except at Saanich $5 \mathrm{~m}$ where nets were suspended at $5 \mathrm{~m}$ below surface. Nets were cleaned or changed whenever density of fouling organisms appeared to impede water circulation.

At each visit, shell heights of 20 randomly selected oysters from each age class, were measured with vernier calipers $( \pm 0.5 \mathrm{~mm}$ ). Shell height was measured as the distance from the end of the umbo to the ventral shell margin (Galtsoff 1964). Shell height of these oysters was previously shown to be highly correlated to dried meat weight (Brown \& Hartwick 1988, in press a).

Duplicate water samples (ca 2 to $4 \mathrm{~h}$ apart) were taken each month for measurement of temperature, salinity, chlorophylls $a, b$ and $c$, carotenoids, $\mathrm{pH}$, dissolved oxygen, total particulate matter (TPM), particulate inorganic matter (PIM) and particulate organic matter (POM). A third monthly sample was usually taken within 24 to $48 \mathrm{~h}$. All water samples were collected about $5 \mathrm{~m}$ up-current of the oyster nets at a depth equivalent to the mid-point of the net.

Water temperature $\left( \pm 0.05 \mathrm{C}^{\circ}\right)$ and salinity $( \pm 0.05$ ppt) were measured using a YSI Model 33 S-C-T meter. Peabody Ryan Model ' $J$ ' thermographs provided a continous temperature record. Secchi depth $( \pm 0.05 \mathrm{~m}$ ) was measured at each sampling site with a $30 \mathrm{~cm}$ diameter white and black disc lowered over the shaded side of the vessel or pier. Dissolved oxygen concentrations $\left(\mathrm{ml} \mathrm{O}_{2}\right.$ [NTP] $\mathrm{l}^{-1}$ ) were determined by Winkler titration procedure (Strickland \& Parsons 1982). A portable Beckman $\mathrm{pH}$ meter was used for $\mathrm{pH}$ readings in the field.

Water samples $(0.5$ to 1.01$)$ for both phytoplankton pigments and particulate matter were collected in a 31 Van Dorn bottle, then passed through a $300 \mu \mathrm{m}$ mesh to remove zooplankton and large debris. Pigment samples were immediately filtered through $47 \mathrm{~mm}$ diameter Millipore AA filters and quick-frozen in the field following the method of Strickland \& Parsons (1982) for spectrophotometric determination of acetone-extracted chlorophylls $a, b$ and $c$ and carotenoids. Suspended particulate matter samples were filtered in the field through pre-weighed GF/C Whatman glass microfibre filters, previously ashed for $2 \mathrm{~h}$ at $450^{\circ} \mathrm{C}$. Filters were then rinsed with 2.0 to $3.0 \mathrm{ml}$ of distilled water, sucked dry and quick frozen. TPM (mg $\mathrm{l}^{-1}$ ) was determined after drying the filter at $60^{\circ} \mathrm{C}$ for $12 \mathrm{~h}$. After ignition of the filter at $450^{\circ} \mathrm{C}$ for $5 \mathrm{~h}, \mathrm{POM}$ and PIM were determined from loss in weight and weight of residue, respectively. Laboratory determination of chlorophyll pigment extinction coefficients and particulate matter concentrations was carried out within $1 \mathrm{wk}$ after sampling.

Polynomial regressions were fitted to shell height data for both age classes using BMDP program P5R. The cubic polynomial equation is comparable to the Von Bertalanfy growth model (MacDonald \& Thompson 1985) with additional advantages of relaxation of the constraint for asymptotic growth and suitability for multiple comparisons requiring a linear model (Roff 1980). To reduce multicollinearity between regression coefficients, a $x-\bar{x}$ transformation was used throughout (Neter et al. 1985). Order of the polynomial was determined by testing each coefficient $\left(\beta_{0}, \beta_{1}, \beta_{2} \ldots \beta_{m}\right)$ against the null hypothesis of $H_{0}: \beta_{m}=0$. If the null hypothesis was accepted, then growth was described by a polynomial of order $m-1$ Pair-wise comparisons between similar coefficients were done for all possible combinations of sites. The possibility of making a Type I error increases when a 2-sample test is used for multiple comparisons (Zar 1984). This test was made more conservative by applying the Bonferroni approximation which divides the significance level by the number of site comparisons or $n$ where $n$ was 9 and 10 for Year 0 and Year 1 oysters, respectively (Neter et al. 1985). Groupings of sites for discriminant analysis (using BMDP P7M) were based upon comparisons of polynomials fitted to shell height data. Sites which had non-significant differences between all similar coefficients of their respective growth polynomials were groupcd together.

All environmental variables were entered into multivariate analyses after checking for high multicollinearity. The decision to apply a $\log _{10}$ transformation to a particular variable was based upon normality of the univariate frequency distribution and patterns of residuals from multivariate analyses (Zar 1984). For each site, average condition of a environmental variable over a particular monthly period $\left(V_{a}\right)$ was determined by the equation

$$
V_{a}=\left(V_{i}+V_{i+1}\right) / 2
$$

where $V_{1}$ and $V_{i+1}=$ means of triplicate or duplicate field observations at the beginning and end of the month, respectively.

Monthly instantaneous growth rate $\left(G_{30}\right)$ was entered into multiple regression analysis as the dependent variable and defined as:

$$
G_{30}=\left(\log _{e}\left(H_{t+1} / H_{t}\right) /\left(\log _{e} D\right)\right) \times 30
$$

where $H_{t+1}=$ mean shell height ( $\mathrm{mm}$ ) of the current month $(\mathrm{n}=20) ; H_{t}=$ mean shell height of the previous month; $D=$ number of days between observations (Ricker 1975). The $\log _{e}$ transformation of $D$ served to further detrend residuals in the multiple regression 
analysis. In stepwise multiple regressions (BMDP P2R), both forward and backward stepping were used with $F$-to-enter and $F$-to-remove values set to 3.0 . Since the purpose of the analysis was exploratory rather than predictive, setting a low $F$ value was justified to examine all relevant environment variables (Dixon 1983)

\section{RESULTS}

Growth in shell height for both year classes was highly variable between certain sites. Final mean monthly shell height $(\mathrm{n}=20)$ in August 1985 ranged from $56.6 \mathrm{~mm}( \pm 7.7 \mathrm{SD})$ at West Vancouver to 100.2 $\mathrm{mm}( \pm 8.7 \mathrm{SD})$ at Okeover Inlet for Year 0 (Fig. 2) and from $68.9 \mathrm{~mm}$ ( $\pm 11.5 \mathrm{SD})$ to $108.5 \mathrm{~mm}( \pm 23.8 \mathrm{SD})$ for Year 1 oysters (Fig. 3). Cubic polynomials described shell height growth of Year 0 (Table 1) and Year 1 (Table 2) oysters at all sites, except Bowen Island Year 1 where coefficients $\beta_{2}$ and $\beta_{3}$ were non-significant. For comparative purposes, a cubic polynomial was fitted to these data although, according to the statistical method used, growth of this group of oysters was significantly different. Variation in growth between sites was largely determined by testing for differences in coefficient $\beta_{0}$. When $\beta_{0}$ was significantly different between 2 sites, subsequent differences were usually found in comparisons of coefficients $\beta_{1}$ and $\beta_{2}$ Differences between coefficient $\beta_{3}$ were non-significant in all comparisons. Since a $x-\bar{x}$ transformation was used, $\beta_{0}$ was shell height $(y)$ at the study's midpoint $(x=\bar{x})$.

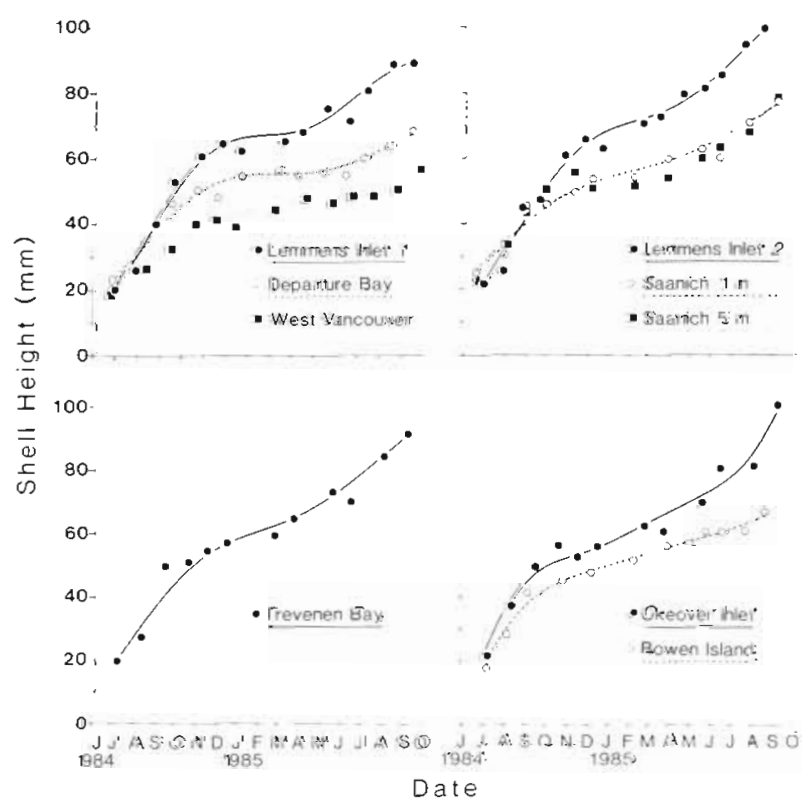

Fig. 2. Crassostrea gigas. Monthly mean ( $\mathrm{n}=20$ ) shell height (mmi growth of Year 0 oysters at 9 sites

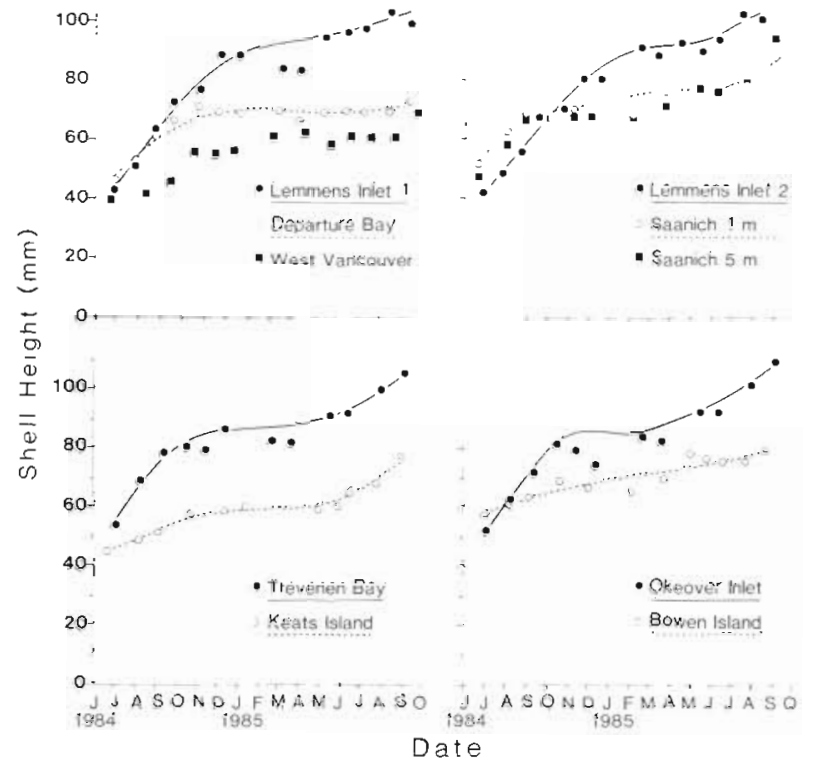

Fig. 3. Crassostrea gigas. Monthly mean ( $\mathrm{n}=20$ ) shell height $(\mathrm{mm})$ growth of Year 1 oysters at 10 sites

On the basis of shell height comparisons for either year class, sites were placed into a high, medium or low growth group (Table 3). Differences in growth between sites within the same group were non-significant; however, differences between sites in different groups were significant $(p<0.05$ after Bonferroni approximation). The high growth group consisted of Trevenen Bay, Okeover Inlet and Lemmens Inlet 1 and 2. Departure Bay, Bowen Island and Saanich $1 \mathrm{~m}$ and $5 \mathrm{~m}$ have significantly lower growth and comprised the medium growth group. The low growth group consisted of West Vancouver and Keats Island (Year 1 only for Keats Island because Year 0 nets were lost in a storm).

Environmental data, presented in detail elsewhere (Brown \& Hartwick 1988, in press a), are summarized here. Water temperatures ranged from a summer maximum of 17.0 to $21.6^{\circ} \mathrm{C}$ to a winter minimum of 2.5 to $7.8^{\circ} \mathrm{C}$. Seasonal fluctuations were significant; however, during a given month, temperatures varied little between sites and there were only minor differences in site-specific cumulative degree-days (Brown \& Hartwick, in press a). At most sites, monthly salinity levels remained above $20 \mathrm{ppt}$ year round. The exceptions were Bowen and Keats Islands and West Vancouver where monthly salinity readings were frequently below 20 ppt. particularly during April to August 1985

Phytoplankton blooms occurred bi-annually at most sites; once in late summer or early fall (August to October) and again in early spring (March to May). Highest mean monthly $(n=10)$ chlorophyll a levels were recorded in September-October 1984 at Lemmens Inlet $1\left(49.09 \mathrm{\mu g} \mathrm{l}^{-1} \pm 40.90 \mathrm{SD}\right)$ and Inlet 2 
Table 1. Crassostrea gigas. Parameters of polynomial regressions fitted to Year 0 shell height data from 9 sites. $p<0.001$ for all regressions

\begin{tabular}{|lcccccrrrr|}
\hline & $\begin{array}{c}\text { Lemmens } \\
\text { Inlet 1 }\end{array}$ & $\begin{array}{c}\text { Lemmens } \\
\text { Inlet 2 }\end{array}$ & $\begin{array}{c}\text { Trevenen } \\
\text { Bay }\end{array}$ & $\begin{array}{c}\text { Okeover } \\
\text { Inlet }\end{array}$ & $\begin{array}{c}\text { Departure } \\
\text { Bay }\end{array}$ & $\begin{array}{c}\text { Saanich } \\
1 \mathrm{~m}\end{array}$ & $\begin{array}{c}\text { Saanich } \\
5 \mathrm{~m}\end{array}$ & $\begin{array}{c}\text { Bowen } \\
\text { Island }\end{array}$ & $\begin{array}{c}\text { West } \\
\text { Vancouver }\end{array}$ \\
\hline$\beta^{0}$ & 67.93 & 70.56 & 61.35 & 61.52 & 55.05 & 55.35 & 53.46 & 53.94 & 45.41 \\
$\beta^{1}$ & 0.07 & 0.09 & 0.08 & 0.07 & 0.02 & 0.06 & 0.03 & 0.04 & 0.03 \\
$\beta^{2}\left(\times 10^{-3}\right)$ & -0.25 & -0.17 & -0.14 & 0.06 & -0.21 & -0.14 & 0.001 & -0.14 & -0.06 \\
$\beta^{3}\left(\times 10^{-5}\right)$ & 0.26 & 0.24 & 0.19 & 0.24 & 0.22 & 0.14 & 0.21 & 0.16 & 0.11 \\
$r^{2}$ & 0.87 & 0.84 & 0.79 & 0.86 & 0.72 & 0.76 & 0.75 & 0.73 & 0.72 \\
$\mathrm{n}$ & 215 & 243 & 187 & 187 & 193 & 198 & 205 & 229 & 186 \\
\hline
\end{tabular}

Table 2. Crassostrea gigas. Parameters of polynomial regressions fitted to Year 1 shell height data from 10 sites. $p<0.001$ for all regressions

\begin{tabular}{|lccccccrrrr}
\hline & $\begin{array}{c}\text { Lemmens } \\
\text { Inlet 1 }\end{array}$ & $\begin{array}{c}\text { Lemmens } \\
\text { Inlet 2 }\end{array}$ & $\begin{array}{c}\text { Trevenen } \\
\text { Bay }\end{array}$ & $\begin{array}{c}\text { Okeover } \\
\text { Inlet }\end{array}$ & $\begin{array}{c}\text { Departure } \\
\text { Bay }\end{array}$ & $\begin{array}{c}\text { Saanich } \\
1 \mathrm{~m}\end{array}$ & $\begin{array}{c}\text { Saanich } \\
5 \mathrm{~m}\end{array}$ & $\begin{array}{c}\text { Bowen } \\
\text { Island }\end{array}$ & $\begin{array}{c}\text { Keats } \\
\text { Island }\end{array}$ & $\begin{array}{c}\text { West } \\
\text { Vancouver }\end{array}$ \\
\hline$\beta^{0}$ & 88.68 & 81.76 & 88.20 & 84.23 & 70.66 & 73.51 & 69.68 & 71.15 & 58.38 & 56.71 \\
$\beta^{1}$ & 0.09 & 0.13 & 0.01 & 0.02 & -0.006 & 0.01 & 0.01 & 0.02 & 0.01 & 0.03 \\
$\beta^{2}\left(\times 10^{-3}\right)$ & -0.55 & -0.45 & -0.14 & 0.02 & -0.31 & -0.15 & -0.09 & -0.02 & 0.03 & -0.08 \\
$\beta^{3}\left(\times 10^{-5}\right)$ & 0.21 & 0.10 & 0.24 & 0.24 & 0.19 & 0.14 & 0.19 & 0.06 & 0.14 & 0.09 \\
$r^{2}$ & 0.74 & 0.73 & 0.75 & 0.58 & 0.46 & 0.44 & 0.61 & 0.36 & 0.52 & 0.44 \\
$\mathrm{n}$ & 205 & 190 & 161 & 189 & 219 & 191 & 190 & 166 & 196 & 214 \\
\hline
\end{tabular}

Table 3 Crassostrea gigas. Summary of comparisons between polynomial equations fitted to Year 0 and Year 1 shell height data from 10 sites. $p<0.05$; ns: not significant

\begin{tabular}{|c|c|c|c|c|c|c|c|c|c|}
\hline & $\begin{array}{c}\text { Lemmens } \\
\text { Inlet } 1\end{array}$ & $\begin{array}{l}\text { Lommens } \\
\text { Inlet } 2\end{array}$ & $\begin{array}{c}\text { Treveñein } \\
\text { Bay }\end{array}$ & $\begin{array}{c}\text { Okeuves } \\
\text { Inlet }\end{array}$ & $\begin{array}{c}\text { Departure } \\
\text { Bay }\end{array}$ & $\begin{array}{c}\text { Saanich } \\
1 \mathrm{~m}\end{array}$ & $\begin{array}{l}\text { Saanich } \\
5 \mathrm{~m}\end{array}$ & $\begin{array}{l}\text { Bowen } \\
\text { Island }\end{array}$ & $\begin{array}{l}\text { Keats } \\
\text { Island }\end{array}$ \\
\hline $\begin{array}{l}\text { Lemmens } \\
\text { Inlet } 2\end{array}$ & ns & & & & & & & & \\
\hline $\begin{array}{l}\text { Trevenen } \\
\text { Bay }\end{array}$ & ns & ns & & & & & & & \\
\hline $\begin{array}{l}\text { Okeover } \\
\text { Inlet }\end{array}$ & ns & ns & ns & & & & & & \\
\hline $\begin{array}{l}\text { Departure } \\
\text { Bay }\end{array}$ & $\cdot$ & - & - & · & & & & & \\
\hline $\begin{array}{l}\text { Saanich } \\
1 \mathrm{~m}\end{array}$ & $\cdot$ & - & $\cdot$ & • & ns & & & & \\
\hline $\begin{array}{l}\text { Saanich } \\
5 \mathrm{~m}\end{array}$ & $\cdot$ & • & $\cdot$ & • & ns & ns & & & \\
\hline $\begin{array}{l}\text { Bowen } \\
\text { Island }\end{array}$ & $\cdot$ & • & - & • & ns & ns & ns & & \\
\hline $\begin{array}{l}\text { Keats } \\
\text { Island }^{1}\end{array}$ & $\cdot$ & . & . & • & . & . & - & . & \\
\hline $\begin{array}{l}\text { West } \\
\text { Vancouver }\end{array}$ & $\cdot$ & $\cdot$ & • & $\cdot$ & $\cdot$ & • & $\cdot$ & • & ns \\
\hline
\end{tabular}

$\left(38.93 \mu \mathrm{g} \mathrm{l^{-1 }} \pm 22.99 \mathrm{SD}\right)$. Subsequent blooms of lower magnitude occurred at these sites during March-April 1985. Maximum monthly means $(n=2)$ at Trevenen Bay and Okeover Inlet were 11.36 ( $\pm 3.32 \mathrm{SD}$ ) and 8.96 $\mu \mathrm{g} \mathrm{l}^{-1}$ ( $\left.\pm 2.07 \mathrm{SD}\right)$, respectively, during June-July 1985. Multiple phytoplankton blooms observed in Saanich Inlet $1 \mathrm{~m}$ and $5 \mathrm{~m}$ had maximum monthly means $(n=2)$ of 12.48 and $15.28 \mu \mathrm{gl}^{-1}( \pm 2.28 \mathrm{SD})$, 
respectively, during the period April to June 1985. Based on comparisons of cumulative chlorophyll adays, overall monthly chlorophyll a levels at Saanich Inlet and Departure Bay were the lowest among all sites while Lemmens Inlet, Trevenen Bay and Okeover Inlet had the highest (Brown \& Hartwick, in press a). Annual maximum chlorophyll a levels 19.79 to 47.28 $\mu \mathrm{g} \mathrm{l}^{-1}$ ) at Bowen Island, West Vancouver and Keats Island coincided with low salinity readings in May and June 1985. Nutrient inputs associated with large volume freshwater discharges from nearby river systems during the spring probably increased phytoplankton biomass at these sites (Parsons et al. 1969, Stockner et al. 1979); however, pigment concentrations were much lower throughout the rest of the year.

Particulate organic matter (POM) levels closely corresponded to monthly trends in phytoplankton pigment concentrations. Maximum monthly mean $(\mathrm{n}=3)$ POM levels occurred during September 1984 at Lemmens Inlet 1 (10.90 $\left.\mathrm{mg} \mathrm{l}^{-1} \pm 7.60 \mathrm{SD}\right)$ and Inlet 2 $\left(9.70 \mathrm{mg} \mathrm{l}^{-1} \pm 0.42 \mathrm{SD}\right)$. High monthly mean $(\mathrm{n}=3)$ concentrations were also observed at Trevenen Bay $\left(6.25 \mathrm{mg} \mathrm{l}^{-1} \pm 0.1 \mathrm{SD}\right)$ and Okeover Inlet $\left(6.00 \mathrm{mg} \mathrm{l}^{-1}\right.$ $\pm 0.42 \mathrm{SD})$. The remaining sites had much lower $(<5.0$ $\mathrm{mg} \mathrm{l}^{-1}$ ) monthly POM levels. Monthly mean PIM concentrations ranged between 1.0 and $16.0 \mathrm{mgl}^{-1}$ at Lemmens Inlet, Saanich Inlet, Trevenen Bay and Okeover Inlet. Lower monthly concentrations, ranging between 0.0 and $8.0 \mathrm{mg} \mathrm{l}^{-1}$, occurred at Bowen and Keats Island and West Vancouver.

At most sites, Secchi depth appeared to follow trends in phytoplankton biomass with maximum depth $(>10$ $\mathrm{m}$ ) in the winter and minimum depth (2 to $5 \mathrm{~m}$ ) during phytoplankton blooms. Dissolved oxygen levels ranged between 5.12 and $11.97 \mathrm{mg} \mathrm{l}^{-1}$ which converted into a range of percent saturation of 73 to $209 \%$. Measured $\mathrm{pH}$ values varied little between sites and ranged between 7.80 and 9.27

Since clusterings of sites based upon comparisons of growth polynomials were similar for both age classes, only one discriminant function was determined, consisting of 2 canonical variables (CV) (Table 4). Significant variables included by step-wise selection criteria were water temperature and salinity, and $\log _{10}$-transformed POM, Secchi depth, carotenoids and dissolved oxygen. The function was highly significant (Bartlett's $\chi^{2}=73.2, p<0.001, \mathrm{df}=12, \mathrm{n}=92$ ) and appeared to best distinguish low growth sites from medium and high growth sites (Fig. 4). In the classification matrix, low growth group cases were categorized correctly $85.0 \%$ of the time while percentages of cases properly classified for medium and high groups were $52.8 \%$ and $72.2 \%$, respectively

In Table 4 , the relative contribution or importance of a particular variable in the discriminant function was evaluated by its correlation $(r)$ to each CV (W. Krane, Dept of Psychology, Simon Fraser Univ., Burnaby, BC, Canada, pers. comm.). CV1 primarily distinguished low growth sites from medium and high growth sites on the basis of salinity $(r=0.78), \operatorname{POM}(r=0.58)$ and Secchi depth $(r=0.35)$. Medium and high growth sites were separated from each other by CV2 for which POM $(r=0.69)$, Secchi depth $(r=-0.58)$ and carotenoids $(r=0.39)$ were the most important variables. Salinity had a lower correlation to CV2 indicating that salinity differed much less in comparison to food supply between medium and high growth sites. Water temperature and dissolved oxygen have very low correlations to both CVs because for any given month conditions were similar among sites.

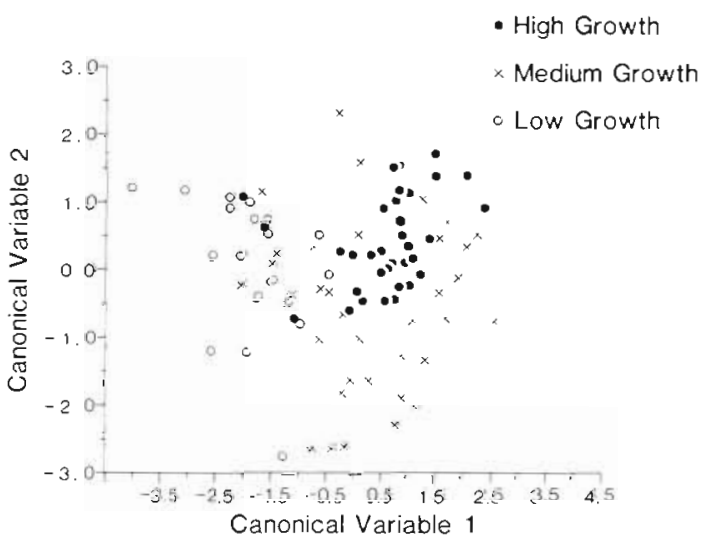

Fig. 4. Scatter plot showing separation of growth groupings of sites by the 2 canonical variables

Table 4. Coefficients of discriminant function and correlations $(r)$ of variables to canonical variables (CV)

\begin{tabular}{lcccc|}
\hline Variable & CV1 & CV2 & Correlation to CV1 & Correlation to CV2 \\
\hline Salinity & 0.206 & 0.010 & 0.78 & 0.20 \\
$\log _{10}$ POM & 1.303 & 5.178 & 0.58 & 0.69 \\
$\log _{10}$ Secchi depth & 5.743 & -8.364 & 0.35 & -0.58 \\
$\log _{10}$ carotenoids & 1.176 & -2.102 & 0.05 & 0.39 \\
$\log _{10}$ dissolved oxygen & 4.445 & -4.997 & 0.13 & 0.21 \\
Water temperature & 0.112 & -0.115 & 0.08 & 0.04 \\
\hline
\end{tabular}


Monthly instantaneous growth rates $\left(G_{30}\right)$ were almost twice as high for Year 0 oysters (Fig. 5) as for Year 1 oysters (Fig. 6). For both age classes, maximum growth rates occurred in July and August 1984 and gradually declined over the fall months to zero in winter. Growth increased in spring of 1985 but summer growth rates were considerably lower than those of the previous year. According to step-wise multiple regression analysis of growth and environmental data, chlorophyll $b$

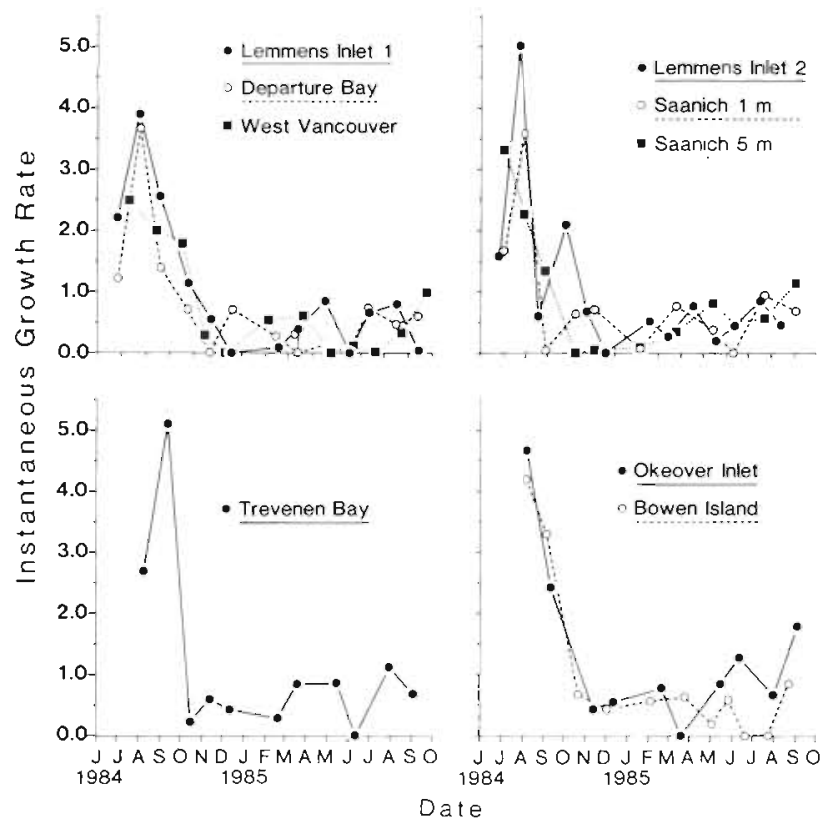

Fig. 5. Crassustrea gigas. Munlhiy instantaneous growth rates for Year 0 oyster shell height at 9 sites

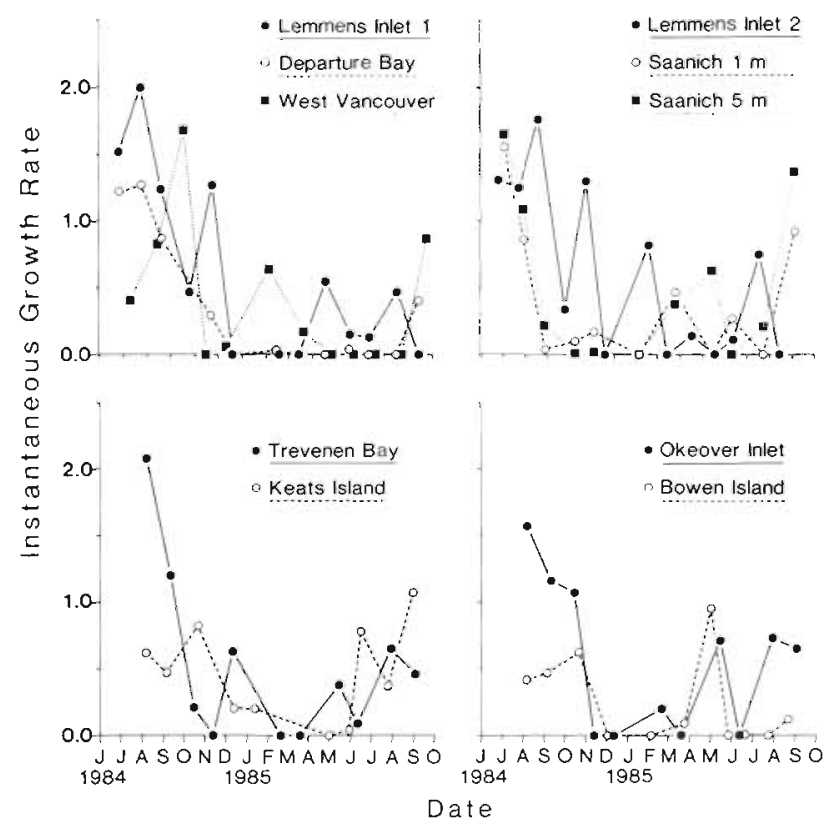

Fig. 6. Crassostrea gigas. Monthly instantaneous growth rates for Year 1 oyster shell height at 10 sites concentration (Fig. 7) and water temperature (see Brown \& Hartwick, in press a), explained $34 \%$ $(p<0.001)$ of variation in $\log _{10}$-transformed instantaneous growth rate in both age classes (Table 5). Chlorophyll $b$ had a greater influence on growth rate than water temperature, based on comparison of standardized partial regression coefficients which indicate relative influences of individual independent variables upon the dependent variable (Zar 1984).

Bivalve growth rate is known to be a function of size and age, so initial shell height of each monthly period was included as an independent variable in a second set of regression analyses (Bayne \& Newell 1983, Hall 1984). Inclusion of initial size increased the explained proportion of growth variation for Year 0 and Year 1

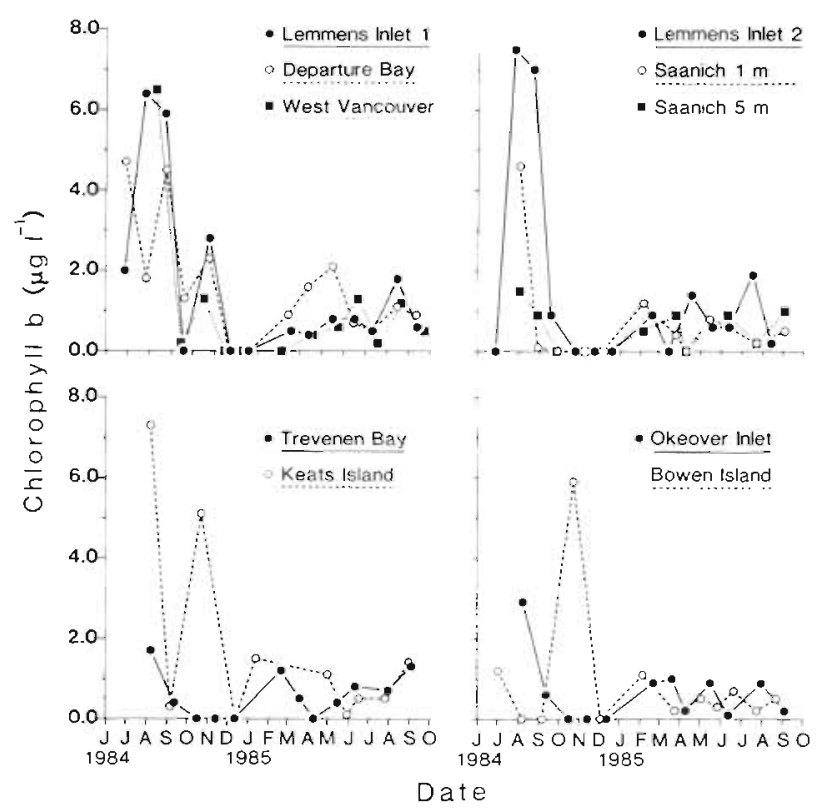

Fig. 7. Monthly mean ( $\mathrm{n}=3$ ) chlorophyll $b$ concentration $\left(\mathrm{mg} \mathrm{l}^{-1}\right)$ at 10 sites

oysters to $62 \% \quad(p<0.001)$ and $44 \% \quad(p<0.001)$, respectively (Table 5). For Year 0 oysters, initial size had a negative influence on growth rate while water temperature and salinity had lesser, positive effects and chlorophyll $b$ was excluded. Initial size also had a negative influence on Year 1 growth rate but water temperature $\mathrm{h}$-ad a positive effect of almost equal magnitude. Chlorophyll $b$ and salinity had positive but reduced infliences, in comparison to the previous analysis which excluded initial size as a variable.

\section{DISCUSSION}

In the present study, differences in site-specific growth curves were related to variations in salinity and 
Table 5. Crassostrea gigas. Multiple regression equations of monthly instantaneous growth rate $\left(G_{30}\right)$ against environmental factors and initial size. Standardized regression coefficients are in parentheses. All regressions are highly significant $(p<0.001)$. CB: chlorophyll $b\left(\mu \mathrm{g} 1^{-1}\right)$; WT: water temperature $\left({ }^{\circ} \mathrm{C}\right)$ i S: salinity (ppt); IS: monthly initial shell height (mm)

\begin{tabular}{|c|c|c|c|c|c|c|c|c|c|c|c|c|}
\hline & & $\beta^{0}$ & & Step 1 & & Step 2 & & Step 3 & & Step 4 & $r^{2}$ & $\mathrm{n}$ \\
\hline \multicolumn{13}{|l|}{ Year 0} \\
\hline $\log _{10} G_{30}$ & $=$ & -0.026 & + & $\begin{array}{c}0.370 \log _{10} C B \\
(0.388)\end{array}$ & + & $\begin{array}{c}0.014 W T \\
(0.292)\end{array}$ & & & & & 0.34 & 106 \\
\hline $\log _{10} G_{30}$ & $=$ & 1.111 & - & $\begin{array}{c}0.783 \log _{10} \text { IS } \\
(-0.642)\end{array}$ & + & $\begin{array}{c}0.016 \mathrm{WT} \\
(0.345)\end{array}$ & + & $\begin{array}{l}0.011 \mathrm{~S} \\
(0.194)\end{array}$ & & & 0.62 & 106 \\
\hline \multicolumn{13}{|l|}{ Year 1} \\
\hline $\log _{10} G_{30}$ & $=$ & -0.046 & + & $\begin{array}{c}0.287 \log _{10} \mathrm{CB} \\
(0.422)\end{array}$ & + & $\begin{array}{c}0.009 \mathrm{WT} \\
(0.262)\end{array}$ & & & & & 0.34 & 115 \\
\hline $\log _{10} G_{30}$ & $=$ & 0.856 & + & $\begin{array}{c}0.141 \log _{10} \mathrm{CB} \\
(0.207)\end{array}$ & + & $\begin{array}{c}0.011 \text { WT } \\
(0.321)\end{array}$ & - & $\begin{array}{c}0.576 \log _{10} \text { IS } \\
(-0.370)\end{array}$ & + & $\begin{array}{l}0.008 \mathrm{~S} \\
(0.214)\end{array}$ & 0.44 & 115 \\
\hline
\end{tabular}

food supply. Monthly growth rates were largely affected by oyster size, food supply and water temperature.

Low growth sites (Keats Island and West Vancouver) frequently have mean monthly salinity lower than 20 ppt while higher salinity levels occurred at sites in medium and high growth groups. According to Quayle (1969) and Bernard (1983), somatic growth in Crassostrea gigas occurs between 16 and 31 ppt with optimal conditions ranging from 20 to $25 \mathrm{ppt}$. Low salinity levels ( $<20 \mathrm{ppt}$ ) are more likely to be limiting to growth since $C$. gigas has been successfully cultivated in highly saline ponds of almost 40 ppt (King 1977). In adverse salinity conditions, the oyster may close its shell and cease feeding (Pierce 1971). Rapid fluctuations in salinity impart a significant metabolic cost and ventilatory recovery may take several days in oysters subjected to salinity changes greater than $10 \%$ (Bernard 1983). Acclimation to low salinity levels at low growth sites and Bowen Island would have been especially difficult during periods of high freshwater run-off from the nearby Fraser River in spring and summer when salinity levels sometimes fluctuated between 12.5 and 21.5 ppt over a tidal cycle (J. R. Brown unpubl.). Reduction in assimilated ration due to shell closures and additional metabolic costs associated with maintenance of osmotic balance under a stressful salinity regime may explain lack of growth in oysters at West Vancouver and Keats Island, even during elevated food concentrations between May and July 1985

Indices of food supply, particularly POM, were highly important in separation of growth categories. Correlation between POM and oyster growth is in agreement with previous findings (Malouf \& Breese 1977. Widdows et al. 1979). A high scope for oyster growth (as defined by Bayne \& Newell 1983) would have occurred at sites where high POM: TPM ratios coincided with peak annual water temperatures.
POM: TPM ratio at Lemmens Inlet sites ranged from $88.0 \%$ in summer to $25.0 \%$ in winter (Fig. 8). Ratios were generally reduced for low growth sites, such as West Vancouver which ranged from 39.0 to $52.0 \%$. High ratios occasionally occurred at other medium and low growth sites but usually during months with low water temperatures or critical salinity levels which would have caused an overall reduction in scope for growth.

Widdows et al. (1979) concluded that the proportion of total seston comprised of POM could be as important as absolute concentration because a high PIM concentration could dilute ingested ration. Growth of cultured

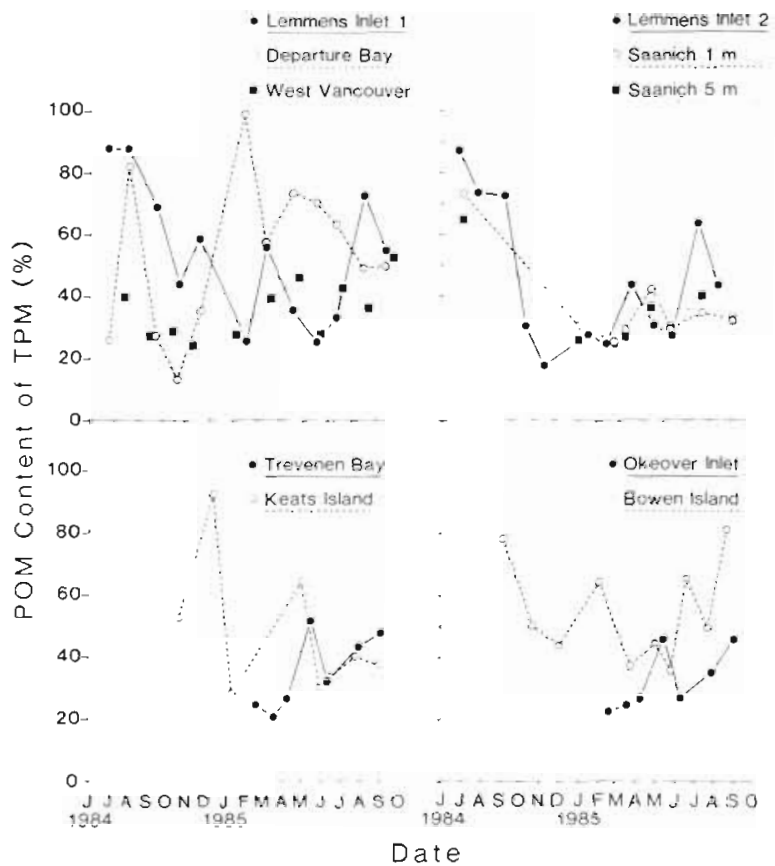

Fig. 8. Monthly mean $(n=3)$ percentage of total particulate matter (TPM) comprised of particulate organic matter (POM) at 10 sites 
scallops Chlamys islandica (O. F. Miller) was inhibited when POM was less than $20 \%$ of total seston (Vahl 1980, Wallace \& Reinsnes 1985); however, Bernard (1983) proposed that feeding behaviour and mechanisms in oysters are adapted to maximum particle concentrations in the environment. The addition of low amounts of silt to algal cultures fed to Mytilus edulis significantly increased growth over that of mussels fed pure algal solutions (Kiorboe et al. 1981), possibly because silt particles can absorb organic compounds (Bayne \& Newell 1983). Newell \& Jordan (1983) suggested that Crassostrea virginica can maintain a positive energy balance even when relative amounts of food particles are low through active particle selection and ingestion. In the study sites, the range of PIM concentrations $\left(0.0\right.$ to $\left.16.0 \mathrm{mg} \mathrm{l}^{-1}\right)$ was far below levels (>75.0 $\mathrm{mg} \mathrm{l}^{-1}$ ) perceived to limit oyster growth (Bernard 1983).

In some environments, a significant portion of POM is refractory and not utilized as food by suspension feeders (Widdows et al. 1979, Soniat et al. 1984). In the present study, POM concentrations generally followed chlorophyll a levels from which usable food ration for suspension feeders can be estimated. In natural phytoplankton populations, the carbon:chlorophyll a ratio can vary between 25 and 60 , depending upon species composition and nutritional condition (Strickland 1960, Parsons \& Takahashi 1973). In British Columbia waters the predominant phytoplankton are members of Chlorophyceae and Skeletonema spp. (Stockner \& Cliff 1975, Stocknes ei di. 1979), ihus a ratio of 26 is a suitable approximation (Parsons 1961). Phytoplankton organic matter (OM) was calculated from the equation $O M=2.14 \times C$, where $C$ is the amount of phytoplankton carbon (mg) determined from the carbon: chlorophyll a ratio (Widdows et al. 1979, Soniat et al. 1984). In Lemmens Inlet, percentage of TPM composed of OM was highest $(8.9$ to $22.6 \%$ ) in June to October 1984 and lowest $(0.0$ to $0.2 \%$ ) in winter (Fig. 9). West Vancouver had a maximum of $31.0 \%$ in June 1985 and a minimum of $0.0 \%$ in November 1984. At this site, periods with the highest percentage of phytoplankton organic matter coincided with lowest annual salinity levels which probably caused the observed low growth rates in oysters.

Total food material may also include non-algal sources of organic matter such as detritus or bacteria. Widdows et al. (1979) and Soniat et al. (1984) utilized a comprehensive 'food' measurement for suspension feeders which was the sum of measured lipids, carbohydrates and proteins. Over oyster beds in Galveston Bay, Texas, Soniat et al. (1984) determined that 'food made up a maximum of $11 \%$ of total seston. In waters of southwest England, $25 \%$ of the seston consisted of 'food' during peak annual periods (Widdows et al.

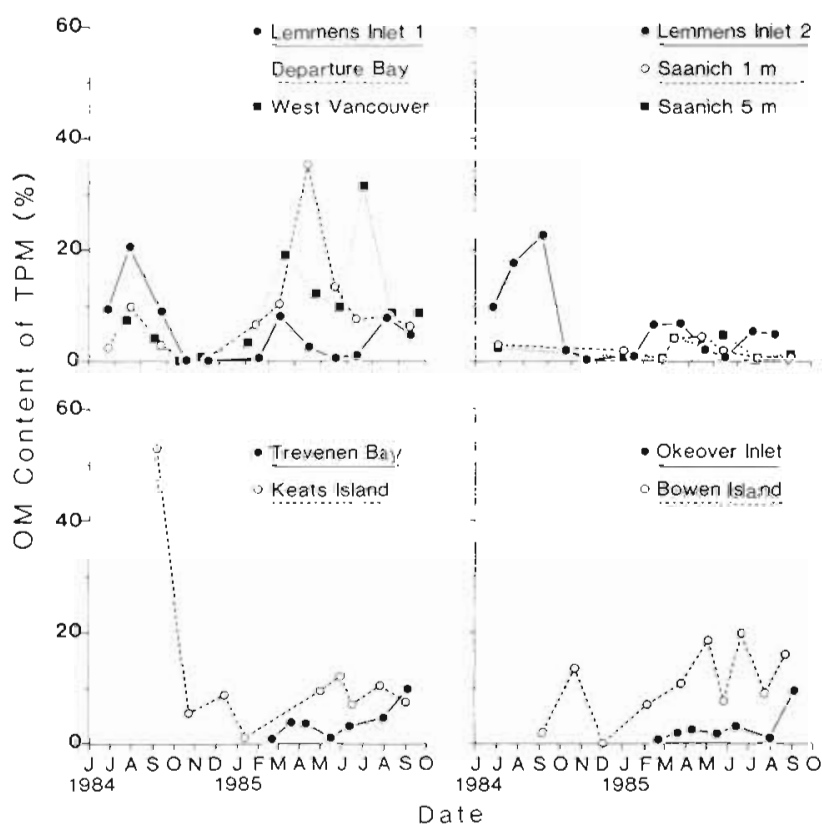

Fig. 9. Monthly mean $(\mathrm{n}=3)$ percentage of TPM comprised of phytoplankton organic matter (OM) at 10 sites

1979). In both studies, chlorophyll a concentrations corresponded to 'food' levels and during annual maximum 'food' levels in the seston, phytoplankton organic matter comprised 68.0 to $69.7 \%$ of the measured components, therefore, in British Columbia waters, total food ration may be even higher than estimated if nonalgal sources are also considered.

Secch depth was negatively correlated to CV2 which distinguished medium from high growth sites. Correlation of POM and carotenoids to CV2 suggests that Secchi disc transparency at medium and high growth sites was affected by phytoplankton or POM. Conversely, Secchi depth was positively correlated with CV1 which separated low growth sites from medium and high growth sites. High correlation of salinity to CV1 is indicative of the effect freshwater influx has on low growth sites, therefore, Secchi disc visibility at these sites may be more significantly affected by suspended sediment concentrations associated with Fraser River run-off (Harrison et al. 1983).

Temperature was not a significant factor in distinguishing between sites with different growth characteristics because temperatures for a given month were similar among sites (Brown \& Hartwick 1988, in press a). Monthly water temperatures in well-mixed coastal waters vary little within the latitudinal range covered in the field study (Thomson 1981). Over much wider latitudinal distances, however, differences in mean annual water temperatures were correlated to site-specific variation in Crassostrea virginica growth (Butler 1953).

Group separation by the discriminant function may 
have possibly been improved by inclusion of variables related to fouling organisms and water currents. Low growth sites, West Vancouver and Keats Island, and 2 medium growth sites, Bowen Island and Departure Bay, occasionally had heavy mussel settlements which have been shown, qualitatively, to have a negative impact on oyster growth (Michael \& Chew 1976). Medium growth sites generally had weaker tidal flow and water exchange compared to high growth sites. Depletion of food sources may have occurred in the immediate vicinity of oysters under these conditions, causing a reduction in energy intake. Much stronger tidal flows were observed at Trevenen Bay and Okeover Inlet, which have similar oysters growth rates but lower POM and chlorophyll a concentrations compared to other high growth sites in Lemmens Inlet. Water currents have been shown to increase bivalve filteration rates slightly (Walne 1972) but of greater importance may be the number of food particles per unit time coming into contact with the bivalve (Fréchette \& Bourget 1985).

Food supply, water temperature and, to a lesser extent, salinity were the principal environmental factors affecting monthly growth rate according to multiple regression analysis. For both Year 0 and Year 1 oysters, however, these variables accounted for less than half of the seasonal variation in growth. Initial size had a considerable effect on growth rates because growth efficiency in bivalves declines with increasing age and size (Bayne \& Newell 1983). Inclusion of a size variable greatly increased the proportion of variance explained by the Year 0 growth regression model. Year 1 growth model fit was less improved by the addition of monthly initial shell height, which indicated that other possible variables influenced growth in older oysters. Gametic production may have affected growth since Year 1 oysters were capable of spawning by summer 1985 (Quayle 1969) and some gonadal material was observed in dissected oysters. Reallocation of energy from somatic growth to gametic production occurs in giant scallops Placopecten magellanicus (MacDonald \& Thompson 1986), and could be the final determinate of growth rate in mature bivalves (Bayne \& Newell 1983)

Regression model fit may have also been reduced by temporal variations in environmental factors which eluded the sampling program. Fréchette \& Bourget (1987) proposed that variability in food supply over a tidal cycle could reduce mussel growth rate. Conversely, Langton \& McKay (1976) found that Crassostrea gigas spat had faster growth rates when fed under a discontinous regime compared with a continous one. In the present study, tidal cycle fluctuations in salinity were greater at low growth sites, but almost equal variances in chlorophyll pigment and POM con- centrations and water temperature were observed among all sites ( $\mathrm{J}$ R. Brown unpubl.).

In regression equations which lacked initial size as an independent variable, available food as estimated by chlorophyll $b$ concentration was of greater importance than water temperature. Elvin \& Gonor (1979) also found that food levels explained $96 \%$ of variance of growth of Mytilus californianus Conrad while water temperature accounted for only $3 \%$. For $2 \mathrm{M}$. edulis populations in England, food ration explained the same high proportion of seasonal variance in growth regardless whether or not temperature was included in multiple regression analysis (B. L. Bayne unpubl, data in Bayne \& Newell 1983). Kirby-Smith \& Barber (1974) concluded that growth of bay scallops Argopecten irradians (Say) in nature was temperature dependent provided food concentrations were not limiting. Ventilation function in the Pacific oyster is greatly reduced at temperatures below 8 to $10^{\circ} \mathrm{C}$ which typically occur during winter in British Columbia (Quayle 1969, Bernard 1983). Low food levels at these temperatures are not critical because metabolic requirements of the oyster are reduced (Bernard 1983). In spring and summer, high water temperatures combined with elevated levels of food supply result in a high scope for growth (Mann \& Ryther 1977. Bayne \& Newell 1983). Such a situation during the summer of 1984 probably induced high growth of oysters at the high growth sites Lemmens Inlet 1 and 2. Conversely, high water temperature and low food ration have been shown to cause negative growth in Crassostrea gigas (Malouf \& Breese 1977 ) and $M$. edulis (Bayne \& Widdows 1978, Incze et al. 1980). A.t West Vancouver and Keats Island, low chlorophyll a and POM levels during the month (August 1984) of maximum annual temperature, acted in concert with sub-optimal salinity conditions, to reduce oyster growth.

Correlation of oyster growth to chlorophyll $b$ rather than chlorophyll a concentrations may be indicative of the role of certain phytoplankton species in oyster diets. Chlorophyll $a$ is ubiquitous to all species of phytoplankton but the chlorophyll $a+b$ system is found only in the Classes Chlorophyceae, Euglenophyceae and Prasinophyceae which are small flagellates ( $<10$ um length), frequently referred to as nanoplankton (Parsons 1961, Parsons \& Takahashi 1973). In a British Columbia inlet, nanoplankton (5 to 60 um length) and ultraplankton ( $<5$ um length) were very abundant, particularly, flagellate members of Chlorophyceae (Pyramimonas grosii and Chlamydomonas sp.) and Euglenophyceae (Eutreptiella marina) (Buchanan 1966). In an oyster culture area in England, Askew (1972) observed a high biomass of Chlorophyceae and Euglenophyceae species and large populations of chlorophyll $b$ rich phytoplankton have 
been reported in coastal waters elsewhere (Hallegraeff 1981, Vernet \& Lorenzen 1987). Incze et al. (1980) suggested that nanoplankton may be an important nutritional component of mussel diets. Retention efficiency of the filtration apparatus of Crassostrea virginica, and probably $C$. gigas, rises sharply as particle size increases from 1 to $4 \mu \mathrm{m}$ then reaches a plateau which is unchanged for particle sizes up to $12 \mu \mathrm{m}$ (Haven \& Morales-Alamo 1970). In British Columbia waters, mean sizes (about $3.5 \mu \mathrm{m}$ ) of predominant nanoplankton species are in the retention range of oysters (Buchanan 1966). Further studies are necessary to determine the nutritional role of nanoplankton in the diets of bivalves in their natural habitats.

The discriminant function and multiple regression models presented here have potential applications in assessing the suitability of coastal areas for oyster culture and modelling oyster growth, respectively. Statistical models should be used with caution in resource management if the accuracy of prediction beyond the range of data used in model formulation has not been fully ascertained. In southern British Columbia waters, the discriminant function could be used to distinguish between areas of different quality for oyster culture. However, recent efforts have derived a model for evaluating site suitability for oyster culture over a wider range of environmental conditions by utilizing methods previously developed for modelling habitat requirements of wildlife species (Brown \& Hartwick 1988). The multiple regression model equations presented here have been modificd into various growiti functions and integrated with a survival component to develop a production model for Pacific oyster culture, which will be the subject of a future paper (Roland \& Brown unpubl.).

Acknowledgements. W G. Roland and I. Sutherland of the British Columbia Ministry of Agriculture and Fisheries greatly assisted in collection of field data and laboratory analyses. Dr W. Krane of SFU provided valuable statistical advice. Financial support was provided by a B. C. Science Council G.R.E.A.T Award and a grant from the B. C. Ministry of the Environment. I wish to thank Drs. E. B. Hartwick, C. J. Langdon and B. A. MacDonald for their reviews of this manuscript.

\section{LITERATURE CITED}

Appeldoorn, R. S. (1983). Variation in the growth rate of Mya arenaria and its relationship to the environment as analyzed through Principal Components Analysis and the $\omega$ parameter of the von Bertalanffy equation. Fish. Bull. U. S. 81: $75-84$

Askew, C. G. (1972). The growth of oysters, Ostrea edulis and Crassostrea gigas in Emsworth Harbour. Aquaculture 1: $237-259$

Bayne, B. L., Newell, R. C. (1983). Physiological energetics of marine molluscs. In: Saleuddin, A. S. M., Wilbur, K. M. (eds.) The Mollusca: physiology, Vol 4 (1). Academic Press, New York, p. 407-415

Bayne, B. L., Widdows, J. (1978). The physiological ecology of two populations of Mytilus edulis L. Oecologia 37: 137-162

Bernard, R. F. (1983). Physiology and the mariculture of some Northeastern Pacific bivalve molluscs. Can. Spec. Publ. Fish. Aquat. Sci. 63

Brown, J. R., Hartwick, E. B. (1988). A habitat suitability index model for suspended tray culture of the Pacific oyster, Crassostrea gigas Thunberg. Aquaculture \& Fisheries Management 19: 107-124

Brown, J. R., Hartwick, E. B. (in press a). Influences of temperature, salinity and available food upon suspended culture of the Pacific oyster, Crassostrea gigas: I. Absolute and allometric growth. Aquaculture 70

Brown, J. R., Hartwick, E. B. (in press b). Influences of temperature, salinity and available food upon suspended culture of the Pacific oyster, Crassostrea gigas: II. Condition index and survival. Aquaculture 70

Buchanan, R. J. (1966). A study of the species composition and ecology of the protoplankton of a British Columbia inlet. $\mathrm{Ph}$. D. thesis, University of British Columbia, Vancouver, British Columbia, Canada

Butler, P. A. (1953). Oyster growth as affected by latitudinal temperature gradients. Comm. Fish. Rev. 15: 7-12

Dame, R. F. (1972). Day degree growth models for intertidal oysters. Contr. mar. Sci. 19: 107-112

Davis, J. C. (1975). Minimal dissolved oxygen requirements of aquatic life with emphasis on Canadian species: a review. J. Fish. Res, Bd Can. 32: 2295-2332

Dickie, L. M., Boudreau, P. R., Freeman, K. R. (1984). Influences of stock and site on growth and mortality in the blue mussel (Mytilus edulis). Can. J. Fish. Aquat. Sci. 41: 134-140

Dixon, W J. (ed.) (1983). BMDP Statistical software. University of California Press, Berkeley

Elvin, O W., Gonor, J. J. (1979), The thermal regime of an intertidal Mytilus californianus Conrad population of the central Oregon coast. J. exp. mar. Biol. Ecol. 39: 265-279

Fréchette, M., Bourget, E. (1985). Energy flow between the pelagic and benthic zones: factors controlling particulate organic matter available to an intertidal mussel bed. Can. J. Fish. aquat. Sci. 42: 1158-1165

Fréchette, M., Bourget, E. (1987). Significance of small-scale spatio-temporal heterogeneity in plankton abundance for energy flow in Mytilus edulis. Mar. Biol. 94: 231-240

Galtsoff, P. S. (1964). The American oyster, Crassostrea virginica Gmelin. U.S. Fish Wildl. Serv. Fish. Bull. 64: 18

Hall, S. (1984). A multiple regression model of oyster growth Fish. Res. 2: 167-175

Hallegraeff, G. M. (1981). Seasonal study of phytoplankton pigments and species at a coastal station off Sydney: Importance of diatoms and the nanoplankton. Mar. Biol. 61: 107-118

Harrison, P. J., Fulton, J. D., Taylor, F. J. R., Parsons; T. R. (1983). Review of the biological oceanography of the Strait of Georgia: pelagic environment. Can. J. Fish. Aquat. Sci. 40: $1064-1094$

Haven, D. S., Morales-Alamo, R. (1970). Filtration of particles from suspension by the American oyster Crassostrea virginica. Biol. Bull. mar. biol. Lab., Woods Hole 139: 248-264

Incze, L. S., Lutz, R. A., Watling, L. (1980). Relationships between effects of environmental temperature and seston on growth and mortality of Mytilus edulis in a temperate northern estuary. Mar Biol. 57: 147-156

King, M. G. (1977). Cultivation of the Pacific oyster, Crassostrea gigas, in a non-tidal hypersaline pond. Aquaculture 11: 123-136 
Kiørboe, T., Mohlenberg, F., Nohr, O. (1981). Effect of suspended bottom material on growth and energetics in Mytilus edulis. Mar. Biol. 61. 283-288

Kirby-Smith, W W., Barber, R. T (1974). Suspension-feeding aquaculture systems: effects of phytoplankton concentration and temperature on growth of the bay scallop. Aquaculture 3: 135-145

Kuwatani, Y., Nishii, T (1969). Effects of $\mathrm{pH}$ of culture water on the growth of the Japanese pearl oyster. Bull. Jap. Soc. scient. Fish. 35: 342-350

Langton, R. W., McKay, G. U. (1976). Growth of Crassostrea gigas (Thunberg) spat under different feeding regimes in a hatchery. Aquaculture 7: 225-233

Loosanoff, V L., Tommers, F. D. (1948). Effect of suspended silt and other substances on the rate of feeding of oysters Science 107: 69-70

Lucas, A., Beninger, P. G. (1985). The use of physiological condition indices in marine bivalve aquaculture. Aquaculture 44: 187-200

MacDonald, B. A., Thompson, R. J. (1985). Influence of temperature and food availability on the ecological energetics of the giant scallop Placopecten magellanicus. I. Growth rates of shell and somatic tissue. Mar. Ecol. Prog. Ser. 25: 279-294

MacDonaid, B. A., Thompson, R. J. (1986). Influence of temperature and food availability on the ecological energetics of the giant scallop Placopecten magellanicus. III. Physiological ecology, the gametogenic cycle and scope for growth. Mar. Biol. 93: 37-48

Malouf, R. E., Breese, W. P. (1977). Seasonal changes in the effects of temperature and water flow rate on the growth of juvenile Pacific oysters, Crassostrea gigas Thunberg. Aquaculture 12: 1-13

Mann, R., Ryther, J. H. (1977). Growth of six species of bivalve molluscs in a waste recycling-aquaculture system. Aquaculture 11: 231-245

Michael, C. P., Chew, K. K. (1976). Growth of Pacific oysters, Crassostrea gigas and related fouling problems under tray culture at Seabeck Bay, Washington. Proc. natl Shellfish. Ass. $66: 34-41$

Neter, J. W., Wasserman, W., Kutner, M. K. (1985). Applied linear statistical models, 2nd edn. R. D. Irwin, Homeland, Illinois

Newell, R. I. E., Jordan, S. J. (1983). Preferential ingestion of organic material by the American oyster, Crassostrea virginica. Mar. Ecol. Prog. Ser. 13: 47-53

Parsons, T R. (1961). On the pigment composition of eleven species of marine phytoplankters. J. Fish. Res. Bd Can. 18: $1017-1024$

Parsons, T R., Stephens, K., LeBrasseur, R. J. (1969). Production studies in the Strait of Georgia. Part I. Primary production under the Fraser River Plume, February to May, 1967. J. exp. mar. Biol. 3: 27-40

Parsons, T. R., Takahashi, M. (1973). Biological oceanographic processes. Pergamon Press, Oxford
Pierce, S. K. (1971). Volume regulation and valve movements by marine mussels. Comp. Biochem. Physiol. 39a: 103-117 Quayle, D. B. (1969). Pacific oyster culture in British Columbia. Can. Bull. Fish. Res. Bd 169: 1-192

Ricker, W. E. (1975). Computation and interpretation of biological statistics of fish populations. Bull. Fish. Res. Bd Can. 191: 1-329

Roff, D. A. (1980). A motion for the retirement of the Von Bertalanffy Function. Can. J. Fish. Aquat. Sci. 37: 127-129

Soniat, T. M., Ray, S. M., Jefferey, L. M. (1984). Components of the seston anc possible available food for oysters in Galveston Bay, Texas. Contr. mar. Sci. 27: 127-141

Stockner, J. G., Cliff, D. D. (1975). Marine phytoplankton production, distribution and species composition in Pendrell and Hotham Sound, British Columbia. Fish. Mar. Serv. Rep. 516: 1-22

Stockner, J. G., Cliff, D. D., Shortreed, K. R. S. (1979). Phytoplankton ecology of the Strait of Georgia, British Columbia. J. Fish. Res. Bd Can. 36: 657-666

Strickland, J. D. H. (1960). Measuring the production of marine phytoplankton. Can. Bull. Fish. Res. Bd 122: 172

Strickland, J. D. H., Parsons, T R. (1982). A practical handbook of seawater analysis, 2 nd edn. Bull. Fish. Res. Bd Can. 167: $1-310$

Thomson, R. E. (1981). Oceanography of the British Columbia coast. Can. Spec. Publ. Fish. Aquat. Sci. 56

Ulanowicz, R. E., Ali, M. L., Vivian, A., Heinle, D. R., Richkus, W. A., Summers, J. K. (1982). Identifying climatic factors influencing commercial fish and shellfish landings in Maryland. Fish. Buil. U. S. 80: 611-619

Ulanowicz, R. E., Caplins, W. C., Dunnington, E. A. (1980) The forecasting of oyster harvest in Central Chesapeake Bay. Estuar, coast, mar. Sci. 2: 101-106

Vahl, O. (1980). Seasonal variations in seston and in the growth rate of the Iceland Scallop, Chlamys islandica (O. F. Miller) from Balsfjord, $70^{\prime}$ N. J. exp. mar. Biol. Ecol. 48: 195-204

Vernet, M., Lorenzen, C. J. (1987). The presence of chlorophyll $b$ and the estimation of phaepigments in marine phytoplankton. J. Plankton Res. 9: 255-265

Wallace, J. C., Reinsnes, T. G. (1985). The significance of various environmental parameters for growth of the Iceland Scallop, Chlamys islandica (Pectinidae), in hanging culture. Aquaculture 44: 229-242

Walne, P. R. (1972). The influence of current speed, body size and water temperature on the filtration rate of five species of bivalves. J. mar. Biol. Ass. U.K. 52: 345-374

Westley, R. E. (1965). Some relationships between Pacific oysters, Crassostrea gigas, condition and the environment. Proc. natl Shellfish. Ass. 55: 19-33

Widdows, J., Fieth, P., Worrall, C. M. (1979). Relationships between seston, available food and feeding activity in the common mussel Mytilus edulis. Mar. Biol. 50: 195-207

Zar, J. H. (1984). Biostatistical analysis, 2nd edn. PrenticeHall, Toronto 